УДК : 321- 049.5(477)

\title{
ДО ПИТАННЯ НОВОЇ КОНЦЕПЦІЇ МІСЦЯ УКРАЇНИ В МІЖНАРОДНІЙ СИСТЕМІ БЕЗПЕКИ
}

Надіслано:

20.09.2020

\section{Губицький Любомир Володимирович}

Рецензовано:

кандидат історичних наук, доцент,

Київський національний торговельно-економічний університет,

м. Київ, Україна

ORCID: 0000-0002-8511-6461

24.10 .2020

lubg@ukr.net

\section{Мельник Ганна Мирославівна}

кандидат історичних наук, доцент,

Київський університет ім. Бориса Грінченка,

м. Київ, Україна

ORCID: 0000-0003-3090-7212

h.melnyk@kubg.edu.ua

У дослідженні зроблено спробу обгрунтувати нову концепцію місця України в міжнародній системі безпеки. За результатами дослідження здійснено аналіз історичних передумов подолання постколоніальних чинників української еліти. Автори наголосили на винятковій ролі Криму для держави-домінанта Чорноморського регіону та висунули гіпотезу про відведення такої ролі для України. Використання порівняльного методу дозволило виокремити ментально-поведінкові засади європейського, азійського, африканського первнів. Українськими перевагами встановлено перехід до обмеження власних потреб, усвідомленої пасіонарної філантропії. Нормативно-ціннісний метод використано для з'ясування історичних визначників загального блага Росії. Пасіонарні здібності українських еліт підтверджено на підставі історичних закономірностей, для чого використано діяльнісний метод. Рекомендовано врахувати виняткову значущість Циркумпонтійської спільноти/цивілізації, що дозволить усунути російські амбіції в акваторії Чорного моря. Регіональні аспірації Російської Федерації останніми роками зіткнулися із вагомим спротивом з боку Туреччини та України. Позицію Європейського Союзу щодо Туреччини позначено як контроверсійну. Позбавлення від токсичного партнераконкурента Російської Федерації для ЄС створить нову геополітичну реальність, в якій пріоритет надаватиметься повазі до міжнародного права. Російські окупаційні адміністрації в державах, які прагнуть вийти з їі орбіти впливу, 
здійснюють політику виснаження та руйнування. Ними стали проросійські анклави Чорноморського регіону - Абхазія, Південна Осетія, Донбас, Крим, Придністров'я. Будівничі «русского мира» планують і реалізовують план дезінтеграції євроспільноти, на який звернула увагу А. Меркель. Запропоновано змінити пріоритети у ставленні до сучасної системи недієвої системи безпеки та визначено складові українських переваг.

Ключові слова: міжнародна система безпеки; Україна; українська еліта; геополітичне становище.

Hubytskyy Lyubomyr, Candidate of Sciences (PhD) in History, Associate Professor, Kyiv National University of Trade And Economics, Kyiv, Ukraine;

Melnyk Hanna, Candidate of sciences (PhD) in History, Associate Professor, Borys Grinchenko Kyiv University, Kyiv, Ukraine

\section{A New Concept of Ukraine's Place in the International Security} System

The analysis attempts to justify a new concept of Ukraine's place in the international security system. According to the results of the study, there was carried out an analysis of the historical preconditions for overcoming the postcolonial factors of the Ukrainian elite. The authors emphasized on the exclusive role of Crimea for the dominant state of the Black Sea region and hypothesized about assigning such a role to Ukraine. The use of the comparative method made it possible to distinguish the mental and behavioral principles of the European, Asian, and African archetype. Ukrainian advantages establish a transition to limiting one's own needs, conscious passionate philanthropy. The normative-value method was used to clarify the historical determinants of Russia's common good. The passionate abilities of the Ukrainian elites were confirmed on the basis of historical regularities, for which the activity method was used. It is recommended to take into account the exceptional importance of the Circumpontian community/civilization, which will eliminate Russia's ambitions within the Black Sea. The regional aspirations of the Russian Federation have faced strong opposition from Turkey and Ukraine in recent years. The European Union's position on Turkey has been described as controversial. Getting rid of a toxic partner competitor of the Russian Federation for the EU will create a new geopolitical reality in which priority will be given to respect for international law. Russia's occupation administrations are pursuing a policy of depletion and destruction in states seeking to break out of its orbit of influence. These were the pro-Russian enclaves of the Black Sea region - Abkhazia, South Ossetia, Donbass, Crimea, Transnistria or Pridnestrian region. The builders of the "Russian world" are planning and implementing a plan for the disintegration of the European community, to which A. Merkel drew attention. It is proposed to change the priorities in relation to the modern system of ineffective security system and identify the components of Ukrainian advantages. 
Key words: international system of safety; Ukraine; Ukrainian elite; geopolitical position; transkontinent.

Губицкий Любомир Владимирович, кандидат исторических наук, доцент, Киевский национальный торгово-экономический университет, 2. Киев, Украина;

Мельник Ганна Мирославовна, кандидат исторических наук, доцент, Киевский университет им. Бориса Гринченко, г. Киев, Украина

\section{К вопросу о новой концепции места Украины в международной системе безопасности}

В исследовании предпринята попытка обосновать новую концепцию места Украины в международной системе безопасности. По результатам исследования проведен анализ исторических предпосылок преодоления постколониальных факторов украинской элиты. Авторы отметили исключительную роль Крыма для государства-доминанта Черноморского региона и выдвинули гипотезу об отводе такой роли для Украины. Использование сравнительного метода позволило выделить ментальноповеденческие принципы европейского, азиатского, африканского начал. Украинскими преимуществами установлено переход к ограничению собственных нужд, осознанной пассионарной филантропии. Нормативноценностный метод использован для выяснения исторических определителей общего блага России. Пассионарные способности украинских элит подтверждено на основании исторических закономерностей, для чего использовано деятельностный метод. Рекомендуется учесть исключительную значимость Циркумпонтийского сообщества/цивилизации, что позволит устранить российские амбиции в акватории Черного моря. Региональные аспирации Российской Федерации в последние годы столкнулись с весомым сопротивлением со стороны Турции и Украины.

Позицию Европейского Союза в отношении Турции определено как противоречивую. Избавление от токсического партнера-конкурента Российской Федерации для ЕС создаст новую геополитическую реальность, в которой приоритет будет предоставляться уважением к международному праву. Российские оккупационные администрации в государствах, которые стремятся выйти из ее орбиты влияния осуществляют политику истощения и разрушения. Ими стали пророссийские анклавы Черноморского региона - Абхазия, Южная Осетия, Донбасс, Крым, Приднестровье. Строители «русского мира» планируют и реализуют план дезинтеграции европейского сообщества, на который обратила внимание А. Меркель. Предложено изменить приоритеты в отношении к современной системе недейственной системы безопасности, и определены составляющие украинских преимуществ. 
Ключевые слова: международная система безопасности; Украина; украинская элита; геополитическое положение; трансконтинент.

\section{Вступ}

Нестабільність міжнародної безпекової ситуації спонукає вчених до пошуку пропозицій та концепцій, які були б підставою для пояснення та формування сучасних змін. Для України залишається вкрай важливим створення та реалізація власної геостратегії.

\section{Аналіз останніх досліджень і публікацій}

На жаль, з цієї проблематики немає вагомих досліджень. Наявні наукові праці в основному підтверджують кордонний характер України, включеність у міжнародну систему безпеки, головні гравці якої не бачать в Україні важливого чинника. Вагомого значення геополітичному положенню українських земель надавали у своїх працях Х. Маккіндер, 3. Бжезінський. Деякі аспекти висвітлюються в дослідженнях В. Василенка, І. В. Кременовської, М.В.Коваль, М. І. Мичко, В. Литвинова, І. Лосєва, О. Мельничук, І. Стороженка, В. Чайки.

\section{Виділення невирішених раніше частин загальної проблеми}

Україну щонайменше від XIII ст. розглядали, або як складову Великого Кордону, складову домінуючого і перманентного впливу московської (російської) ідеї, або як уламок західної, європейської цивілізації, або як територію для поширення духовних основ ісламу. Але чомусь у вказаний період їй було відмовлено у особливій універсальності, оригінальності, цілісності.

\section{Формулювання мети і завдань статті}

Саме пошуку вказаних домінант і присвячене наше дослідження. Визначено наступні завдання: 1) аналіз джерел із заявленої теми; 2) встановлення складових крихкості сучасної системи міжнародної безпеки; 3) виокремлення кластерів та синтез сучасної концепції геополітичного місця України в регіоні та світі.

\section{Виклад основного матеріалу дослідження}

Із Біблії: «Забули будівничі про камінь «краєкутний» (Пс. 117:22). $€$ ще один вислів про камінь, яким себе називає Бог - «камінь зіткнення чи спокуси» (lat. - petros skandale - камінь конфлікту) (Ic. 8:14). «I буде він освяченням, і каменем зіткнення, і скелею спокуси для обох домів Ізраїля, петлею і сіткою для жителів Єрусалиму (Пророцтво про Месію)» (Bibliia, 1992). Очевидно, що в Євангелії від Матвія говориться про камінь основи як про камінь конфлікту. Із ним не треба грати, пересувати, використовувати не за призначенням. Це камінь, призначений для основи всього, якщо ним намагатися маніпулювати, то ця дія перетвориться в руйнівну силу для тих, хто так вчиняє.

Чи є цей камінь таким, що на світлі виблискують його грані? Швидше це камінь загублений, замулений, а можливо знаходиться у багні (болоті озера, 
що згодом, за результатами катаклізму, стало Чорним морем), як діамант з відомого вислову. Власне цим каменем була, $є$ і буде Україна. Саме тому нині настільки вагомим стало для Росії питання духовних «скрепів» у вигляді Криму (із послання Президента РФ В. Путіна Законодавчим зборам РФ у грудні 2014 р.) (Chaika, 2014). Зросійщення власне Криму створюватиме базу для відновлення спільності завдання як для України, що завжди рухалася до моря (за І. Крип'якевичем), так і для Росії, яка перебрала це завдання від України. Духовність неможливо скріпити, обмежити, оточити, як неможливо їі підмінити геополітикою. Тому для України життєво необхідним є відвоювати Крим.

Саме наріжним каменем в Чорноморському регіоні була завжди, $\epsilon$ і буде завжди Україна (Русь, Оріяна, Оратанія, Артанія, Аратта). Кутами цього каменю були і $€$ краї-континенти. Каменем краєкутним у споруді наддержавній пан'європейській, пан'євразійській, пан'африканській. Оскільки Україна знаходиться не лише у центрі Європи, але й у центрі всього надвеликого трансконтиненту - Євроафроазії. Саме у цьому суть України. Як окраїни континентів.

Чи є цей камінь, зважаючи на попереднє твердження тригранним? Швидше всього, що ні. Він, мабуть, $є$ колом (циркум), яке прикрашене великою кількістю трикутників.

Які ж чинники підтверджують вагомість такої засадничої основи? Момент перший - європейський. Без української пасіонарності, пасіонарності автохтонів українських земель не постали б ні Рим, ні Еллада, ні Русь, ні Московія, ні Росія як імперія. Звідси і з'явилася ідея «третього Риму». Україна була і $є$ не першим Римом, а праРимом. Рим перший, Рим другий і Рим третій впали через неміцність фундаменту, який тримався на рабстві мільйонів і комфорті тисяч (пригадаймо концепцію «золотого мільярда»). Перший Рим впав під тиском Великого переселення народів, яке сам і запустив, здійснивши вторгнення на землі германських племен. Тi, у свою чергу, почали міграцію в напрямі Чорного моря у I-II ст. н.е. У IV ст. н.е. готи не зуміли відповісти на азійський виклик гунів, що й призвело до зміни балансу сил в Римській імперії і на території її федератів. I як наслідок - падіння імперії у V ст. Звичайно, була і низка внутрішніх чинників падіння імперії.

Стратегія на майбутнє - відмова від комфорту і рабства, перехід до обмеження потреб і реалізації свободи.

Момент другий - азійський. Приклад із Російською імперією винятково показовий. Український геній прагнув створити величну державу загального блага, уособленням якого мав служити лише імператор (за Ф. Прокоповичем) (Prokopovych, 1979). Із цієї нагоди згадаймо приказку: «Благими намірами викладено дорогу до пекла». Наміри були стратегічно правильними. Витворити принципи держави трансконтинентальної. Із забезпеченням повного контролю 
за Чорним (Руським) морем, а не лише тимчасовим домінуванням запорозьких флотилій створювалися передумови безпечного коридору для функціонування зародку трансконтиненту. Українці удосконалили принципи дії механізму величної держави, але країни не загального блага.

Загальне благо москвини тлумачили і тлумачать вкрай унікально. Оскільки стратегією цього народу i його еліти був загальний блуд (невпорядковані внутрішні та зовнішні відносини) й пекло на землі (зневага до міжнародного права, надання переваги застосуванню насильства), та й самі москвини стверджують: «Насильно мил не будеш», тому й не могли вони сприйняти заклик: «Покайтеся». Несумісність прагнень українського генію та московського прагматизму виявили нежиттєвість очікувань поєднання величі та загального блага. Образно кажучи, «козаки з турецької галери і татарського ясиру потрапили до царського каземату».

Першим і найвагомішим підтвердженням цього $\epsilon$ те, що російське православ'я є щонайменше християнством, а за висловом В. Путіна, швидше нагадує свій антипод - іслам. У цього симбіозу глибокі традиції, які сягають спільних молитов православних москвинів і мусульманських та татар за спільного татарського царя-хана Золотої Орди, починаючи з XIV ст. Як російське православ'я, так і мусульманство характеризуються крайньою ортодоксальністю i фундаменталізмом, а простіше - нетерпимістю. Загальне благо Росії (Московії) визначається імператором чи лідером держави, в сучасних умовах за допомогою 3MI (пропаганди). Загальне благо Росії декількома словами можна записати так: нетерпимість, агресія, приниження, зневага до людини й інших народів.

На поч. XVIII ст. українська еліта усвідомила загрозу ліквідації державних структур України-Гетьманщини царатом, відповіддю на що стало бажання очолити процес створення і розширення Російської імперії. Але новоутворена імперія не стала українською по суті, а лише українською - за вищим, але не найвищим керівництвом. Подібне явище спостерігалося у Речі Посполитій y XVI-XVII ст., де отримало назву сарматизму, яке було утворенням надетнічним, сакральним, становим, ідеологічним. Сарматизм засвідчував зв'язок із народами Азії (Іран), Кавказу (Осетія), Східної Європи (Україна, Росія, Білорусь, Литва), Центрально-Східної Європи (Польща, Угорщина), Західної Європи (Британія, Італія-Рим). Українське козацтво було прихильне до створення на базі «сарматизму» універсальної «річпосполитської» або «шляхетської імперії», яка б гарантувала свободи та співіснування різних культур і народів (Storozhenko, 2014, p. 13). Особливо яскравим представником вказаного напрямку став C. Оріховський (Lytvynov, 2014).

Стратегія на майбутнє - відмова від передачі пасіонарності (ідей, методів, механізмів, структур) іншим народам, навіть за умови смертельної небезпеки. 
Пасіонарність на користь власного народу збереже життя без підтримки інших народів. Або спочатку забезпечення самозбереження, а згодом підтримка розвитку інших.

Момент третій - африканський. Українська традиційна позиція була пов'язана із згадками походів русинів до Царгороду та в акваторію Середземного моря. Тим же маршрутом рухалися запорозькі козаки. Цей момент у російській геополітиці представлений проблемою проток Босфора i Дарданели. Але вирішення цього вузького місця української геополітики і майбутнього світоустрою не у протоках, а у відновленні Циркумпонтійської цивілізації, тобто включенні Туреччини до складу Євроспільноти в короткотривалій перспективі. Чим швидше еліти $€ С$ визначаться на користь Туреччини, тим стабільнішим буде Європейська спільнота. На поч. XXI ст. Європейський Союз опинився у ситуації вибору між Туреччиною та Росією, в якій з XV по XIX ст. перебувала Україна. Можливо, саме тому Росія намагалася шантажувати Україну та Європу турецьким транзитом, але відмовляла Туреччині у зниженні ціни на природній газ у 2015 р. У лютому 2015 р. В. Путін активно проштовхував ідею союзництва 3 Єгиптом через продаж йому зброї. Із 2015 р. РФ активно втрутилася у громадянську війну в Сирії та Лівії. I не дивно, що з 2019 р. російські найманці отримали гідних супротивників у вигляді турецької армії.

Поблажливість автохтонів українських земель до латинян (римлян) обернулося заміною змагання на закон, примус, криваві розваги, структури центру-провінції. Плебс царського, республіканського та імператорського Риму був на достатньо високому рівні розвитку, але його вимоги не перевищували «хліба і видовищ». Поблажливість автохтонів українських земель до москвинів (росіян) обернулася заміною змагання на беззаконня, катування, гіпертрофовану структуру центру-провінції. Плебс Москви $\epsilon$ на достатньо високому рівні розвитку, але його вимоги не перевищують гасла: «Горілка, балалайка, матрьошка». Хліб римлян перетворився на горілку росіян, а видовища римлянина перетворилися на балалайку із матрьошкою (уособлення багаторівневості свідомості, розчленованості особистості, нестійкості психіки).

Звернемо увагу, протистояння автохтонів українських земель та Римської, Візантійської імперії в минулому, і нині Російською Федерацією розпочиналися із конфлікту за Крим, Херсонес (Севастополь). Римська імперія взяла під контроль грецькі міста-колонії, які були мирно допущені на українські, а не грецькі землі Криму. Але зуміла ї утримати лише до 275 р. н.е. Візантійський вплив на Крим закінчився втратою незалежності князівства Феодоро, володарі якого, як правило, підтримували некримських, або неукраїнських володарів. Наприклад, володарі кримських князівств і міст підтримували Візантію, а не Русь у X-XIII ст.; Золоту Орду, а не кримських володарів у XIII-XIV ст.; Туреччину, а не кримського хана в XV ст. У кінцевому 
рахунку це й стало причиною знищення Феодоро. Маємо приклади нестійкості позиції, визнання пріоритетом збереження залежності через встановлення зверхності домінуючої регіональної сили. Отже, за умов хиткості договірної бази Кримський півострів, як правило, підпадав під вплив найсильнішої держави Чорноморського регіону. У січні 2015 р. країни ЄС та НАТО визнали, що анексія Росією Криму змінила баланс сил у регіоні і несе небезпеку Південній Європі.

Контроль України над Кримом РФ визнавала до часу, поки бачила в самій Україні буферну зону, яка ніколи не стане складовою території підконтрольної НАТО. Входження України разом із Кримом до території, підконтрольної НАТО, чи то безпосередньо, чи через механізми часткового союзництва відкрило перед РФ перспективу втрати якщо не домінуючого, то принаймні вагомого впливу у Чорноморсько-Кавказькому регіоні.

Економічні втрати РФ, зниження курсу рубля, міжнародні санкції, падіння ціни на нафту призвели до початку процесу піврозпаду Росії, який 3 необхідністю призведе до повного розпаду (див. Януш Бугайський) (The Hill, 2019). Прояв суті росіянина-москвина - агресія, «токсичність», неповага до договорів, нехтування честю, гідністю, дружбою, здоров'ям, життям людини, у XXI ст. викликали непряму відповідь світу у вигляді ізоляції. Така картина Росії могла б бути окреслена європейськими фахівцями.

Але фахівці «русского мира» бачать картину Росії, Європи і світу дещо іншою. Це розпад євроатлантичної єдності, відновлення кордонів періоду Варшавського договору. Як казав Карл Маркс: «Я питаю вас, що ж змінилося? Чи зменшилася небезпека з боку Росії? Hi, тільки розумове засліплення панівних класів Європи сягнуло межі. Насамперед, за визнанням їі офіційного історика Карамзіна, незмінною залишається політика Росії. Ї̈̈ методи, її тактика, іiі прийоми можуть змінюватися, але дороговказ цієї політики, світове панування, залишається незмінним» (Losiev, 2016).

Як вдало помітив Ігор Лосєв: «Путін хоче нав'язати себе людству як світового лідера поза конкуренцією і встановити неочекістський «орднунг»тотальну корупцію та бандократію, себто новітнє варварство і своєрідний варіант середньовіччя, такий собі режим Януковича у світовому масштабі. У цьому сенсі він становить загрозу всій цивілізації Заходу, недаремно Ангела Меркель звинуватила його в руйнуванні європейського ладу» (Losiev, 2015).

Знищення на окупованій бойовиками території Донбасу в 2014-2015 pp. доріг, залізниць, мостів, аеропортів, руйнування житлових споруд, електростанцій, лікарень, викрадання, катування, убивства людей, заборона викладати українську мову й історію України $€$ поведінка окупанта, а не визволителя. Саме так поводяться на територіях, контроль над якими $\epsilon$ непостійним, нестабільним, окупант не впевнений у своїй силі, хиткості його 
позиції. Або розглядає ці злочини як засіб для залякування заради прийняття його умов. Це сучасний відповідник шантажу, підкупу, залякування, вбивств.

Українська влада і еліта не усвідомлює силу стратегії, або через іiї неусвідомлення, або через небажання діяти стратегічно. Стратегічно, але не в інтересах окупанта. Оскільки досі українська еліта постколоніальна, тому перебуває у колі поглядів колоніальної стратегії. Як доречно помітила Оксана Мельничук: «Українська культура - той самий тонкий вимір, по якому проходить Другий український фронт. Фронт боротьби за право України на майбутнє. Цей тонкий вимір був і є звичним середовищем для українського суспільства. Біда України в тому, що незважаючи на це, протягом усіх часів незалежності він категорично відсутній в політикумі» (Melnychuk, 2015).

На підтримку позиції О. Мельничук зацитуємо ії: «Культурна політика це регулятор суспільних відносин. Хочуть чи не хочуть це визнавати наші політики - але культура є ключовим фактором стійкого розвитку та єдиною можливістю консолідації спільнот за умови розумного регулювання». Саме так, нагадаємо те, що відомо усім, але коментовано, як вигідно ворогу. Україна як метрополія Русь соромиться власної величі, а колонія Русі - Суздаль, Ростов, Москва вважають достатнім лише мати побічне відношення до Русі і можна виставляти вимоги стосовно Києва. Тут доречна народна приказка: «Нахабство друге щастя». Тому Україна ставитиме вимоги стосовно земель Чернігівського князівства. Тому Україна ставитиме вимоги стосовно Кубані. Тому Україна ставитиме вимоги стосовно усіх земель Слобідських козацьких полків. Тому Україна ставитиме вимоги стосовно Криму. Всі ці землі стануть складовими української території (Melnychuk, 2015).

Аксіома російської геополітики XXI ст.: Крим український до часу, допоки Україна слабка, Україна - неспроможна держава. Аксіомою української геополітики XXI ст. має стати: Москва російська до часу, поки Росія слабка. У XVIII ст. Крим перейшов під російську юрисдикцію, оскільки таку позицію поділяла українська козацька еліта Гетьманщини і Запорізької Cічі (KHazin, 2015). У XXI ст. РФ вирішила змінити юрисдикцію Криму без погодження із українською елітою. Такий процес або таємно узгоджений із українською елітою, або він нежиттєздатний.

Слабкість України, як їі розуміли і тиражували для світу російські політики і ЗМІ полягала у цивілізаційній невизначеності, позиції вибору, який неможливо здійснити. На думку російських політиків і політтехнологів, вагома складова українського суспільства (росіяни за походженням, російськомовні українці) тяжіла до «русского мира», прагнула стати його складовою. Але це за умови, що самі громадяни РФ не розуміють суті «русского мира». Суть «русского мира» в формі «кримнаш», «ДНР», «ЛНР» і реальних їх проявах викликали сумнівні оцінки, як серед росіян, так і серед мешканців 
Донбасу, так і серед мешканців усієї України. Якщо і були до 2014 p. прихильники «русского мира» в Україні, то після реалізації принципів цього проєкту їх стало на порядок менше. До 2014 р. більшість українців були підвладні концепції, що росіяни - брати українців. Однак війна змінила градацію уподобань як росіян, так і українців. Лише третина мешканців Донбасу прагнуть від'єднатися від України, а $56 \%$ мешканців Донбасу бачили Україну своєю батьківщиною (Sereda, 2019). Тобто, жодної цивілізаційної невизначеності в українському суспільстві не прослідковується, а це свідчить лише про одне: Україна - сильна держава.

Слабкість Росії в ізольованості народу від зовнішнього світу, у замкнутості російської еліти, втраті інтелектуального потенціалу, виразній військовій артикульованості зовнішньої політики, яка набуває форми гібридних війн. Росія стала агресором, нехай, усвідомленим на даний момент, як гібридний. В основі агресії лежать концепції: права націй на самовизначення (Придністров'я, Абхазія, Північна Осетія, Крим) та права на «исконно русские земли» (Новоросія). Об’єднує ці концепції прагнення відновити імперську велич. Оскільки світові лідери (США, ЄС, Китай) вкрай спокійно, лояльно поставилися до вказаних актів агресії, то вони, швидше за все, матимуть продовження. Вказані акти перетворять Росію на слабку у воєнному плані лише у одномуєдиному випадку - за умови, що вона буде оголошена агресором. Професор В. Василенко на підставі актів міжнародного права довів, що Росія здійснила проти України акт агресії (Vasylenko, 2014).

Професор В. Василенко констатує, що нині владна еліта й українське суспільство повинні усвідомити, що Росія веде проти України тотальну війну. Ïї кінцевою метою $є$ не відторгнення частини території і не позбавлення нашої країни права цивілізаційного вибору, а знищення українства як явища й української державності як такої. Тому неодмінними пунктами порядку денного в гарантуванні національної безпеки України мають стати: 1) відновлення сектору безпеки; 2) розробка і здійснення україноцентричної гуманітарної політики як засобу відсічі гуманітарній агресії Росії; 3) запровадження програм європейської та євроатлантичної інтеграції з метою набуття Україною повноправного членства в ЄC i НАТO; 4) формування консолідованої офіційної правової позиції щодо протидії збройній агресії РФ та ліквідації її наслідків (Vasylenko, 2014).

Але оскільки українська еліта обрала (з чим важко погодитися) як оптимальну пасивну захисну тактику у відносинах із сусідами, Росією, то сподіватися на активну підтримку великих держав не доводиться. Підтримка від великих держав може з'явиться за наступних обставин: по-перше, за умови, що великі країни визнають бойові дії, здійснювані російською армією на чужій території актом агресії (юридична складова); по-друге, що українська армія 
надаватиме достатнього спротиву російській армії; по-третє, що загроза безпосереднього зіткнення РФ і НАТО розглядається як малоймовірна. Визнання Верховною Радою України 27.01.2015 р. вторгнення російських військ на Донбас актом агресії може призвести до поширення конфліктної зони безпосередньо на країни НАТО (країни Балтії, операція пов'язана із «Латгальською народною республікою» на території Латвії 30.01 .2015 р.), чого відверто бояться європейські політики. Тому для $Є С$ вигідніше зупинити конфлікт на Донбасі за рахунок України (схожу позицію в січні 2015 р. зайняли керівники Греції, Словаччини, Чехії, Австрії). Керівники США, НАТО, ЄС мають великі сумніви у боєздатності Збройних Сил України, особливо у конфлікті із армією РФ. Показово, що речники РФ ще у 2014 р. заявляли, ніби розпочалася Третя світова війна. Це засвідчує психологічну готовність російської еліти до зростання кількості людських жертв (теракти січня 2015 р. у Волновасі, Донецьку, Маріуполі). Чи готові євроатлантичні політики до цих жертв? - питання відкрите. У разі зіткнення євроатлантичної і православно-сибірської цивілізації світ чекає або радіоактивний попіл (за висловом телеведучого Киселева), або розподіл Росії. На думку українського експерта Олега Соскіна, Російська імперія має зникнути. Подальший шлях Росії - або повернення до внутрішніх справ і перетворення своєї території на розвинуту країну, або розпад. Таку думку в інтерв'ю Радіо Свобода висловив професор грузинського Державного університету Ілії, історик, журналіст Олег Панфілов (Rosii zahrozhuie rozpad, 2020).

Українська держава, українська еліта, українське суспільство, українська армія мають великі шанси на перемогу за певних умов. По-перше, за умови визнання РФ агресором, ворогом, якого обов'язково, заради уникнення майбутніх агресивних дій 3 його сторони, треба покарати на умовах беззастережної капітуляції. По-друге, союзниками України у війні проти РФ мають стати не лише країни НАТО, ЄС, США, але й країни, які в недалекому минулому відчули на собі їі агресивні зазіхання (Молдавія, Грузія, Чечня, Білорусь, Казахстан, Азербайджан, Вірменія, Фінляндія, Японія). Вказані держави можуть стати ядром Собору вільних народів - основи ЄвроАфроАзіайського трансконтиненту-наддержави. По-третє, за умов інформаційного забезпечення військового розгрому Росії. Як не дивно, але лише частина першої умови знайшла відображення у новій Стратегії національної безпеки України 2020 p. (Pro rishennia Rady natsionalnoi bezpeky, 2020), а саме визнання Росії агресором.

Україна зі своїм потенціалом і врахуванням пропонованої концепції наддержави-трансконтиненту може долучитися до вирішення глобальних (загальнолюдських) проблем. I тому слушною $\epsilon$ думка Н. Р.Нижник, котра зазначає, що самознищення людства стало можливим і за мирних умов через 
нерозв’язаність глобальних проблем земної цивілізації (Kremenovska, 2010, p. 175).

До таких у загальному вигляді віднесено ті, що концентрують фундаментальні протиріччя сучасної земної цивілізації; стосуються життєвих інтересів кожної людини, соціальної групи, держави, регіону і людства загалом; загрожують подальшому розвитку та збереженню сучасної цивілізації; їх розв'язання вимагає тісної співпраці всіх країн та народів незалежно від ïx соціально-економічного устрою, політичних, ідеологічних чи інших відмінностей (Kremenovska, 2010, p. 175).

\section{Висновки}

Сучасна ситуація в Україні і навколо України засвідчили концентрацію вказаних проблем на окремо взятій території. Вирішення цих проблем на цій території може стати зразком для формування нових структур, в основу функціонування яких будуть покладені якісно нові підстави. На нашу думку, це свобода, стриманість, високий інтелектуальний потенціал, релігійна толерантність. Саме ці складові можуть бути вагомими складовими нової міжнародної політики і нового міжнародного права.

Таким чином, війна в Україні визначила наступні компоненти сучасних міжнародних відносин: перехід до силових методів забезпечення національних інтересів, невиконання міжнародних угод, інформаційна агресія, сепаратизм, релігійний релятивізм, занепад загальнолюдських цінностей.

\section{References:}

1. Bibliia abo knyhy Sviatoho Pysma Staroho i Novoho Zapovitu [Bible or books of Scripture of the Old and New Testaments]. (1992). Kyiv: Ukraina.

2. Chaika, V. (2014). 'Dukhovnye skrepy Vladimira Putina' [Spiritual bonds of Vladimir Putin]. Khvulia, [online]. Available at: https://hvylya.net/analytics/politics/duhovnyie-skrepyi-vladimira-putina.html.

3. Khazin, M. (2015). 'Nashe vse i Krym nash' ["Our everything" and "Our Crimea"]. Radio Svoboda, [online]. Available at: https://www.svoboda.org/a/26795485.html.

4. Kremenovska, I., Koval, M., Mychko, M. (2010). Heopolitychni aspekty natsionalnoi bezpeky y oborony Ukrainy [Geopolitical aspects of national security and defense of Ukraine]. Donetsk: DIuI LDUVS.

5. Losiev, I. (2015). 'Zakhidnyi nevroz Rosii ta rosiiskyi - zakhodu' [Western neurosis of Russia and Russian - the West]. Ukrainskyi Tyzhden [The Ukrainian Week], [online]. Available at: https://tyzhden.ua/Society/128656.

6. Losiev, I. (2016). 'Shliakhom Pietra i Yekatieriny?' [By Peter and Catherine?].

Ukrainskyi Tyzhden [The Ukrainian Week], [online]. Available at: https://tyzhden.ua/History/154643. 
7. Lytvynov, V. (2014). Stanislav Orikhovskyi. Istoryko-filosofskyi portret [Stanislav Orikhovsky. Historical and philosophical portrait]. Kyiv: Akademperiodyka.

8. Melnychuk, O. (2015). 'Druhyi Ukrainskyi front' [The Second Ukrainian Front]. Ukrainska Pravda, [online]. Available at: http://life.pravda.com.ua/columns/2015/01/23/188290/.

9. Pro rishennia Rady natsionalnoi bezpeky i oborony Ukrainy «Pro Stratehiiu natsionalnoi bezpeky Ukrainy» Ukaz Prezydenta Ukrainy: vid 14 veresnia 2020 roku №392/2020 [On the Decision of the National Security and Defense Council of Ukraine "On the National Security Strategy of Ukraine" Decree of the President of Ukraine №392/2020] from September 14, 2020. The Presidential Office of Ukraine, [online]. Available at: https://www.president.gov.ua/documents/3922020-35037.

10. Prokopovych, F. (1979). Filosofski tvory. V 3 tomakh. [Philosophical works. In 3 volumes]. Kyiv: Naukova dumka.

11. Rosii zahrozhuie rozpad - profesor Panfilov [Russia is threatened with disintegration - Professor Panfilov]. Radio Svoboda, [online]. Available at: http://www.radiosvoboda.org/content/article/26810079.html.

12. Sereda, Ye. (2019). 'P'iat rokiv «rosiiskii vesni». Yak sformuvavsia mif pro separatyzm bilshosti na Donbasi' [Five years of the "Russian spring". How the myth of separatism of the majority in Donbass was formed]. Ukrainska Pravda, [online]. Available at: https://www.pravda.com.ua/articles/2019/04/12/7211983/.

13. Storozhenko, I. (2014). 'Formuvannia Zaporizkoi Sichi yak derzhavy-mista: problemy rytsarskoi korporatyvnoi symvoliky ta ideolohii' [Formation of the Zaporizhzhya Sich as a city-state: problems of knightly corporate symbols and ideology]. Prydniprov'ía. Istoryko-kraieznavchi doslidzhennia [Dnieper. Historical and local lore research], no. 12, pp. 5-19.

14. The Hill: Upravliaia raspadom Rossii [Driving the disintegration of Russia]. Khartyia 97 [Charter 97], [online]. Available at: https://charter97.org/ru/news/2019/1/12/319765/.

15. Vasylenko, V. (2014). 'Viina 2014 roku: sproba systemnoho analizu' [War of 2014: an attempt at system analysis]. Tyzhde [The Ukrainian Week], no. 42 (362).

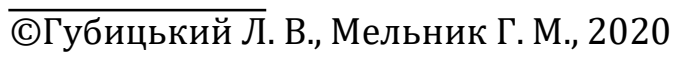

